Electroencephalography and Clinical Neurophysiology

Elsevier Publishing Company, Amsterdam - Printed in The Netherlands

\title{
EEG IN PREDICTION OF HUNTINGTON'S CHOREA. AN EIGHTEEN YEAR FOLLOW-UP
}

\author{
Joseph H. ChandLeR, M.D. ${ }^{1}$
}

(Accepted for publication: January 10, 1966)

\section{INTRODUCTION}

One of the more tragic features of Huntıngton's chorea is the delayed appearance of symptoms until affected individuals are well into, or even past, the age of reproductive capacity. It would be desirable for a number of reasons to be able to identify carriers of the gene responsible for this trait before they reach reproductive age.

Patterson et al. (1948) examıned 26 offspring of diagnosed chorea patients with a battery of tests in an attempt to 1dentify those who would develop the disease in later years EEG examination was felt to have prognostic value Predictions were made which were based on (a) the degree of EEG abnormality, (b) the presence of paroxysmal features, and (c) the presence of slow wave activity over the motor areas.

Twelve offspring with the greatest amount of EEG abnormalıty were desıgnated "most likely to develop chorea" Seven with lesser amounts of abnormality were given a "bare possibility of developıng the disease". For seven offspring with normal EEGs a prediction was made that they "probably would never develop Huntington's chorea".

The purpose of this study is to present a clinical followup of predictions for offspring of Huntington's choreics made by EEG 18-20 years ago, and to evaluate those predictions in relation to current neurologic status of those offspring.

\section{MATERIAL}

During a statewide clınical and genetic survey of Michıgan for Huntıngton's chorea (Reed and Chandler 1958; Reed and Neel 1959; Chandler et al 1960) followup clinical information was obtained for most of the 26 subjects in the EEG prediction study. More recently all except two of the offspring were again located. One was excluded from the study since, in retrospect, it seemed probable she already had Huntington's chorea at the time of the prediction.

Eighteen of the remaining 23 have been examined by the author; reliable institutional and medical reports were gathered for the remaining five.

In the family pedigrees which appear in the publication of the original study of Patterson et al. (1948),

${ }^{1}$ Formerly neurology consultant to Department of Human Genetics, University of Michigan Medical School. Present address : 6815 Castle Drive, Birmıngham, Mich seventeen of the individuals included in the present tabulations may be identified by their generation and individual numbers (Table I)

TABLE I

\begin{tabular}{ccc}
$\begin{array}{c}\text { Kindred } \\
\text { No. }\end{array}$ & $\begin{array}{c}\text { Generation } \\
\text { No }\end{array}$ & $\begin{array}{c}\text { Individual } \\
\text { Nos }\end{array}$ \\
\hline 261 & V & $1,2,3,4,5$ and 6 \\
610 & IV & 10 \\
615 & III & 1,2 and 3 \\
672 & V & 9 \\
756 & VI & $1,3,4$ and 5 \\
819 & V & 2 \\
945 & IV & 6 \\
\hline
\end{tabular}

The original study included two other kindreds, No. 1073 and No. 1075, but those pedigree charts were omitted from that publication. The five individuals in kındred No. 1073 who also had follow-up studies are in generation VI, individual numbers $10,11,12,14$ and 15 . Only one member of kindred No. 1075 was included in both studies $\mathrm{He}$ is number 21 in generation IV.

\section{RESULTS}

Twelve of the offspring eventually developed Huntington's chorea. To date the eleven other subjects have remained clinıcally unaffected.

TABLE II

The results of an 18 year follow-up on the accuracy of the prediction of the development of Huntington's chorea from EEG studies

\begin{tabular}{lccc}
\multicolumn{1}{c}{ Prediction } & $\begin{array}{c}\text { No. of } \\
\text { individuals }\end{array}$ & \multicolumn{2}{c}{ Clinical follow-up } \\
\hline $\begin{array}{l}\text { Choretc } \\
\text { "Most likely to } \\
\text { develop" }\end{array}$ & 10 & 5 & 5 \\
$\begin{array}{l}\text { Abnormal EEG } \\
\text { "Bare possibilıty } \\
\text { of developing" } \\
\text { Borderline EEG } \\
\text { "Probably would } \\
\text { never develop" }\end{array}$ & 7 & 3 & 4 \\
\begin{tabular}{l} 
Normal EEG \\
\hline
\end{tabular} & 6 & 4 & 2 \\
\hline
\end{tabular}

Electroenceph. clin Neurophysiol., 1966, 21 79-80 
Correlating the twelve diagnosed chorea patients with their EEG prediction (see Table II) it was found that: (1) five were predicted "likely to develop chorea"; (2) four were predicted "probably will never develop chorea", (3) three were predicted as having "a bare possibility of developing chorea".

The three predictions of "bare possibility of developing chorea" were considered incorrect. In those who eventually developed chorea, five had been correctly predıcted and seven had been incorrectly predicted

Correlation of eleven unaffected individuals with their predictions are also shown in Table II. Of these five who had been predicted "likely to develop chorea" are now aged respectively $29,42,36,25$ and 25 years. The two who were predicted as "will never develop chorea" are now 26 and 38 years old respectively. The four with "a bare possibility to develop chorea" are now aged $27,33,45$ and 46 years

Assuming that the "bare possibility" group reflects a smail chance of developing the disease then six of the eleven in the unaffected group were predicted correctly and five were predicted incorrectly.

\section{SUMMARY}

EEG as used by Patterson et al (1948) has little value in identifying carriers of the Huntington's chorea tratt Clinical follow-up of predictions for 23 offspring of known choreic patients, 18-20 years later reveals 11 were correct and 12 were incorrect

The author wishes to express his appreciation to Dr J. V Neel and Mrs. R Davidson of the Department of Human Genetics of the University of Michigan Medical School and Mrs M. McDonald for assistance in the preparation of this manuscript

\section{REFERENCES}

Chander, J H, Reed, T. E. and DeJong, R $\mathrm{N}$. Huntington's chorea in Michigan 3. Clinical observations. Neurology (Minneap ), 1960, 10 148-153

Patterson, R. M, Bagchi, B K. and Test, A The prediction of Huntington's chorea . an electroencephalographic and genetic study Amer J. Psychiat, 1948, $104 \quad 786-797$

Reed, T. E and Chandler, J H Huntington's chorea in Michigan 1 Demography and genetics Amer $J$ hum. Genet, 1958, $10 \quad 107-136$

Reed, T. E and NeEl, J V Huntington's chorea in Michigan. 2 Selection and mutation Amer $J$ hum. Genet, 1959, 11: 107-136.

Reference: ChANDLER, J. H. EEG in prediction of Huntington's chorea An eighteen year follow-up. Electroenceph clin. Neurophysiol, 1966, 21 79-80.

\title{
ANALYSE QUANTITATIVE D'ÉLECTROENCÉPHALOGRAMMES RÉPÉTÉS CHEZ LE CHIEN SOUMIS À L'EFFET DU DIÉTHYL LYSERGAMIDE $\left(\mathrm{LSD}_{25}\right)^{1}$
}

\author{
N. Guiti, B. Djahanguiri et H. Mehdizadeh \\ Service de Médecıne Expérımentale et de Pharmacologıe, Faculté de Médecine, Untversité de Téhéran (Iran)
}

(Accepted for publication January 26, 1966)

L'étude du $\mathrm{LSD}_{25}$ chez l'homme et l'anımal en tant que médicament psychomimétique, permettant de reproduire des psychoses algués expérımentales, a des avantages pratiques, surtout du point de vue de la réversıbilité et de la durée plus courte des manifestatıons psychıques par rapport aux psychoses spontanées chez l'homme.

L'analyse des variations de "EEG, parmı les autres critères objectifs, se place au premier rang pour évaluer les effets psychomimétıques du $\mathrm{LSD}_{25}$ et des médicaments analogues. Sugerman et al. (1964) ont montré qu'il y a une similitude étonnante entre l'EEG des sujets trartés par $\mathrm{LSD}_{25}$ et ceux des schizophrènes chronıques

${ }^{1}$ Le diéthyl lysergamıde (Delysıd) nous a été gracieusement fourn par la firme Sandoz.
Ellıngson (1955), Goldsteın (1963) et Goldsteın et al. (1963b) ont montré que l'étude objectıve de ces varıations n'est pas suffisante et ont proposé d'interpréter l'EEG par les méthodes quantitatıves méthode d'intégration automatıque décrite par Drohockı (1948) basée sur l'étude de la somme d'énergie des décharges électrıques par le cortex cérébral.

Les données de la littérature concernant l'effet du LSD $_{25}$ sur l'activité électrique cérébrale sont nombreuses. Parmı celles-ci on peut relever une sérıe des travaux sur l'effet du LSD 25 sur l'EEG (Bradley et al. 1953; Bradley et Elkes 1957, Bradley 1959, Hımwich 1959, Himwich et al. 1959, Goldsteın et al 1963a et b, Hobson 1964), en comparaison avec la schizophrénie chronıque (Murphree et al 1962, 1964a; Pfeiffer et al 1962, Goldstein et al. 1963a et b, Sugerman et al. 1964), avec les autres médicaments

Electroenceph. clin. Neurophysiol , 1966, 21 80-84 